ARTICLE HISTORY: Received: October 12, 2021 Accepted: December 06, 2021 Published: December 13, 2021

УДК 669.184

\title{
АНАЛИЗ ТЕХНОЛОГИЧЕСКИХ ОСОБЕННОСТЕЙ ПЕРЕДЕЛА ФОСФОРИСТЫХ ЧУГУНОВ В ТОМАСОВСКОМ КОНВЕРТЕРЕ
}

\author{
Дида Н.И., Раковский В.С., Лопатина А.О., Галич А.А. \\ Научный руководитель: ассистент Сафонов С.О. \\ Сибирский государственный индустриальный университет, Новокузнеик,
}

\begin{abstract}
Аннотация. Статья посвящена анализу конструктивных особенностей Томасовского конвертера и технологических особенностей выплавки в данном сталеплавильном агрегате, физико-химическим процессам, происходящим в конвертерной ванне, теплового баланса плавки. Приведена характеристика процесса продувки воздухом через пористые блоки в днище агрегата, описано влияние азота на качество стали. Описана конструкция и материалы, применяемые в футеровке Томасовского конвертера.

Ключевые слова: Томасовский конвертер, термодинамика, продувка, футеровка, динасовый кирпич, железоуглеродистый расплав, азот.
\end{abstract}

\section{Введение}

Назначением томасовского процесса является передел фосфористых чугунов, содержащих 1,6-2,2\% Р. Для успешной дефосфорации металла необходимы основные шлаки,следовательно, футеровка конвертера должна быть выполнена из основных материалов.Томасовские конвертеры имеют смолодоломитовую футеровку. Исходными материалами длянее служат обожженный доломит $(52-57 \% \mathrm{CaO}, 35-40 \% \mathrm{MgO})$ и обезвоженная каменноугольнаясмола. Из дробленого доломита, смешанного со смолой, прессуют блоки, которыми и футеруютполость конвертера. Обжиг поверхности футеровки происходит непосредственно в конвертерепри его разогреве и распространяется на всю толщу огнеупоров во время проведения плавок.При обжиге смола коксуется и прочно связывает зерна доломита.

По конструкции томасовский конвертер принципиально не отличается от бессемеровского, но относительные размеры его большие. Так, удельный объем рабочего пространства достигает 1,4 м $3 /$ т против 0,8 1,2 у бессемеровского. Эти увеличенные размеры необходимы ввиду большого количества шлака (30\% против 5-7\%), образующегося при томасовском процессе. Днища конвертеров футеруют на вибрационных машинах или прессах изсмолодоломитовой массы; после формовки в теле днища образуются игольчатые сопла,которые иногда армируют металлическими трубками. Готовые днища подвергают обжигув специальных печах при температуре $600-700^{\circ} \mathrm{C}$.

\section{Особенности применяемых шихтовых материалов}

Томасовский чугун имеет следующий состав, \%: 0,2-0,5 Si; 0,6-1,3 Mn; 1,8-2,2 P; до 0,06 S. Фосфористые чугуны легкоплавки (температура ликвидуса $\left.1050-1100^{\circ} \mathrm{C}\right)$, поэтому их можно заливать в конвертер при 1200 $1250^{\circ} \mathrm{C}$.

Высокое содержание кремния в томасовском чугуне нежелательно, так как дляошлакования кислого оксида $\mathrm{SiO}_{2}$, необходимо дополнительное количество извести. Фосфорявляется главным теплоносителем процесса, по его содержанию томасовские чугуны делятна химически холодные $(<1,8 \%$ Р) и химически горячие $(>2,2 \% \mathrm{P})$. Повышенное содержаниесеры в чугуне допускается потому, что в ходе процесса она может быть удалена на 30 $40 \%$.Содержание углерода в томасовском чугуне $(3,2-3,6 \%)$ ниже, чем в бессемеровском, таккак фосфор снижает растворимость углерода в железе.

В качестве шлакообразующей присадки используют металлургическую известь. Припродувке перегретого или химически горячего чугуна применяют охладители: мелкий стальнойлом, руду и ее заменители.

Термохимия томасовского процесса

Теплота, получаемая ванной от окисления углерода, такая же, как и в бессемеровскомпроцессе, теплота от окисления кремния, марганца и железа различается на величину тепловыхэффектов образования соответствующих силикатов, так как в основном процессе $\mathrm{Mn}$ и Fе остаются в шлаке свободными, а $\mathrm{SiO}_{2}$ связывается в силикатные комплексы с $\mathrm{CaO}$ извести.

Фосфор окисляется с высоким тепловым эффектом для реакции

$$
2[\mathrm{P}]+2,5\left\{\mathrm{O}_{2}\right\}=\left(\mathrm{P}_{2} \mathrm{O}_{5}\right), \Delta \mathrm{H}^{0}=-1080 \text { кДж/мольР } \mathrm{O}_{5},
$$

Теплота шлакования $\mathrm{P}_{2} \mathrm{O}_{5}$ в фосфатные комплексы также значительна, например, для реакции

$$
\left(\mathrm{P}_{2} \mathrm{O}_{5}\right)+4 \mathrm{CaO}_{\text {тв }}=\left(4 \mathrm{CaO} \mathrm{P}_{2} \mathrm{O}_{5}\right), \Delta \mathrm{H}^{0}=-690 \text { кДж/моль, }
$$


В приходную часть теплового баланса томасовской плавки 45\% теплоты вносит жидкий чугун, 55\% экзотермические реакции окисления его примесей. В расходной части балансафизическая теплота металла и шлака составляет 70-72\%, теплота, теряющаяся с отходящими газами, - 22-26\%. Тепловой КПД томасовского процесса составляет 0,70-0,72.

\section{Технология томасовской плавки}

После выпуска очередной плавки в конвертер присаживают расчетное количествоизвести и заливают чугун. Затем включают дутье, ставят конвертер в рабочее положениеи начинают продувку металла. Томасовская плавка состоит из трех периодов. Кривыеокисления примесей в процессе продувки томасовской ванны, изменение ее температуры и состава шлака показаны на рис. 5.

В период I окисляются, главным образом, кремний, марганец и железо, образуяжидкий кислый шлак (силикаты железа и марганца), в котором находятся куски извести.Вследствие низкой температуры начала продувки растворение извести в жидкой частишлака происходит медленно; низкая активность СаО в шлаке препятствует раннему окислению и связыванию фосфора в шлаке.

После снижения концентраций кремния и марганца и разогрева металла начинаетсяпериод II - окисление углерода. Внешним признаком этого периода является появлениенад горловиной конвертера факела пламени. Окисление углерода происходит интенсивно,так как фосфористый металл характеризуется повышенной жидкоподвижностью и хорош перемешивается с газами дутья. Незначительное повышение температуры ванны в этотпериод (см. рис. 1)объясняется затратами теплоты на растворение извести при относительно небольшом тепловом эффекте реакции окисления углерода. Первые два периодапродувки томасовской ванны похожи на бессемеровские.
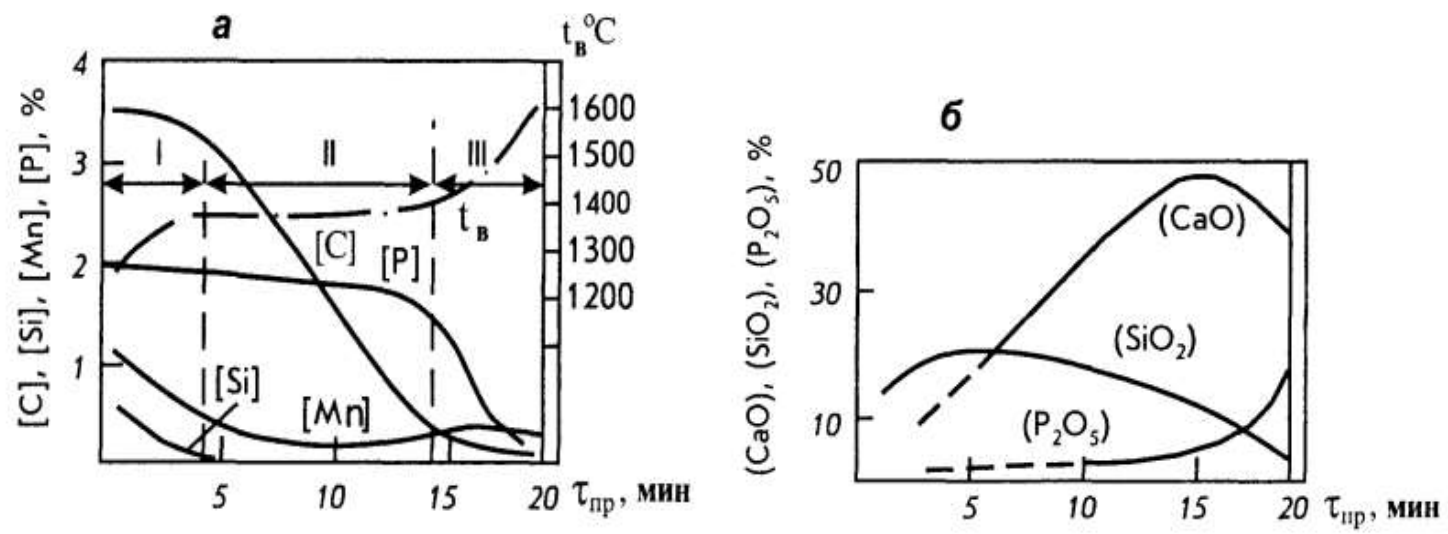

Рисунок 1 - Изменение состава и температуры ванны $t$ (а), состава шлака (б)

Период III -передувка. К концу второго периода в ванне остается небольшое количество элементовпримесей, кроме фосфора, содержание которого уменьшилось незначительно. Следовательно, создаются условия, при которых кислород дутья может расходоваться на окисление фосфора. Одновременно во втором периоде начинает формироваться основной известковый шлак с активностью $\mathrm{CaO}$, достаточной для связыванияокисляющегося фосфора, в фосфатные комплексы, то есть для удержания его в шлаке.

Признаком начала третьего периода считают резкое сокращение факела пламени,что свидетельствует об окончании процесса обезуглероживания и начала дефосфорации.В третьем периоде совсем исчезает пламя и идет почти черный дым, продолжительностьего устанавливают по аналогии с предыдущими плавками и контролируют по секундомеру.

В начале третьего периода шлак остается еще гетерогенным, но оксиды железа икислый оксид $\mathrm{P}_{2} \mathrm{O}_{5}$, переходящие в шлак, быстро растворяют остатки извести, и шлакгомогенизируется. Поэтому процесс дефосфорации протекает с высокой скоростью ипериод передувки длится всего 3-4 мин. Экзотермическая реакция окисления и шлакованияфосфора значительно повышает температуру ванны. По расчетам $1 \%$ окисленного фосфораповышает температуру металла на $120-130^{\circ} \mathrm{C}$, следовательно, за период передувки ваннадолжна нагреться на $220-270^{\circ} \mathrm{C}$. Как видно из диаграммы рис. 5 , в третьем периодепроисходит основной нагрев ванны.

\section{Раскисление томасовской стали}

По окончании продувки конвертер наклоняют и возможно полнее сливают шлак,остатки его загущают угорловины присадками извести или доломита и из-под образовавшегося "мостика" сливают металл в ковш. После продувки в конвертерную ванну вводяттолько кусковой ферромарганец, чтобы он успел раствориться за время слива шлака.Ферросилиций и алюминий присаживают в ковш, на струю металла. 
Томасовский металл всегда получают низкоуглеродистым, поэтому для получениясреднеуглеродистых сталей его следует науглероживать. Для этого обычно применяютжидкий зеркальный чугун, который заливают в ковш непосредственно перед выпускомплавки. Во избежание сильной рефосфорации, использование твердых и порошкообразныхкарбюризаторов (кокса, электродного боя и др.) не допускается. Несмотря на всепредупредительные меры при выплавке спокойной стали, концентрация фосфора в металлеперед разливкой увеличивается обычно на 0,006-0,010\%.

Томасовский фосфатшлак

Фосфатшлак- ценный побочный продукт, в значительной степени определяющийэкономичность всего процесса. Средний химический состав конечного шлака томасовскойплавки следующий, \%: 5-10 $\mathrm{SiO}_{2}, 16-24$ $\mathrm{P}_{2} \mathrm{O}_{5}, 40-50 \mathrm{CaO}, 8-12 \mathrm{FeO}$, остальное - $\mathrm{MnO}, \mathrm{MgO}, \mathrm{Al}_{2} \mathrm{O}_{3}$. Количество шлака обычно составляет 20-24\% от массы чугуна.

Качество фосфатшлака как удобрения определяется содержанием $\mathrm{P}_{2} \mathrm{O}_{5}$ и растворимостьюфосфатов в органических кислотах. При испытаниях растворимость $\mathrm{P}_{2} \mathrm{O}_{5}$ шлака в 2-процентном водном растворе лимонной кислоты должна быть не ниже $90 \%$. Хорошо растворяются ворганических кислотах соединения типа силикатфосфатов кальция: $4 \mathrm{CaO}^{*} \mathrm{P}_{2} \mathrm{O}_{5}=\mathrm{SiO}_{2}$.

При недостатке $\mathrm{SiO}_{2}$ в шлаке образуются труднорастворимые соединения типаапатитов. Особенно нежелательно присутствие в шлаке $\mathrm{CaF}_{2}$, связывающего фосфор внерастворимые фторапатиты. Так, повышение содержания в шлаке фтора с 0,02 до $0,05 \%$ снижает растворимость $\mathrm{P}_{2} \mathrm{O}_{5}$ с 90 до 80\%. Поэтому в томасовском процессе применениеплавикового шпата для разжижения шлака недопустимо.

Для получения высококачественного фосфатшлака в нем должно быть не менее $7-8 \% \mathrm{SiO}_{2}$. Недостающее его количество вводят в шлак при выпуске плавки в виде сухого песка,который хорошо растворяется в горячем шлаке. После застывания шлак измельчают, затемтонко размалывают, фасуют и используют в сельском хозяйстве.

\section{Качество и назначение томасовской стали}

Томасовская сталь характеризуется повышенным содержанием фосфора $(0,040-0,080 \%)$ и азота $(0,015$ $0,025 \%$ ). Эти особенности состава определяют снижение вязкости и пластичности стали, хладноломкость и склонность к старению.

Томасовский металл интенсивно насыщается азотом в период передувки, характеризующейся высокими температурами и отсутствием промывающего эффекта пузырьков $\mathrm{CO}_{2}$ поэтому в современных вариантах томасовского процесса большое внимание уделяютрегулированию температурного режима третьего периода. Наиболее благоприятные результаты были получены при использовании мелкой руды или окалины, вводимых в конвертер в конце второго или в начале третьего периода. Снижение температуры, повышение степени окисленности шлака и металла и одновременное уменьшение расхода дутья снижают содержание азота в готовом металле до 0,012-0,014\%.

Томасовская сталь используется, как правило, для изделий неответственного назначения: строительных профилей, арматурного железа, проволоки, штрипсов для сварных труби др. Этот металл характеризуется хорошей свариваемостью и способностью держатьпокрытия (краски, эмали). Поэтому томасовскую сталь улучшенного качества, то есть спониженным содержанием азота и фосфора и благодаря низкому содержанию углерода,используют для массового производства автомобильного листа.

\section{Список литературы}

1. Конвертерное производство стали. / Б.М. Бойченко - Днепропетровск: Металлургия, 2006. - 453 с.

2. Технологии интенсификации кислородно-конвертерного процесса/ С.О. Сафонов // Наука и молодежь: проблемы, поиски, решения. Труды Всероссийской научной конференции студентов, аспирантов и молодых ученых. - 2021. - С. $177-180$.

3. Изучение влияния (положения, интенсивности) фурмы на параметры реакционной зоны/ В.С. Фадеев, С.О. Сафонов // Наука и молодежь: проблемы, поиски, решения. Труды Всероссийской научной конференции студентов, аспирантов и молодых ученых. - 2021. - С. 193 - 196.

4. Анализ конструктивных особенностей дутьевых устройств для продувки металлического расплава в конвертере/ С.О. Сафонов // Наука и молодежь: проблемы, поиски, решения. Труды Всероссийской научной конференции студентов, аспирантов и молодых ученых. - 2017. - С. $141-143$. 